\title{
ILUSTRACE K DÍLU BOŽENY NĚMCOVÉ ZE SBÍREK ODDĚLENÍ KNIŽNÍ KULTURY KNIHOVNY NÁRODNÍHO MUZEA
}

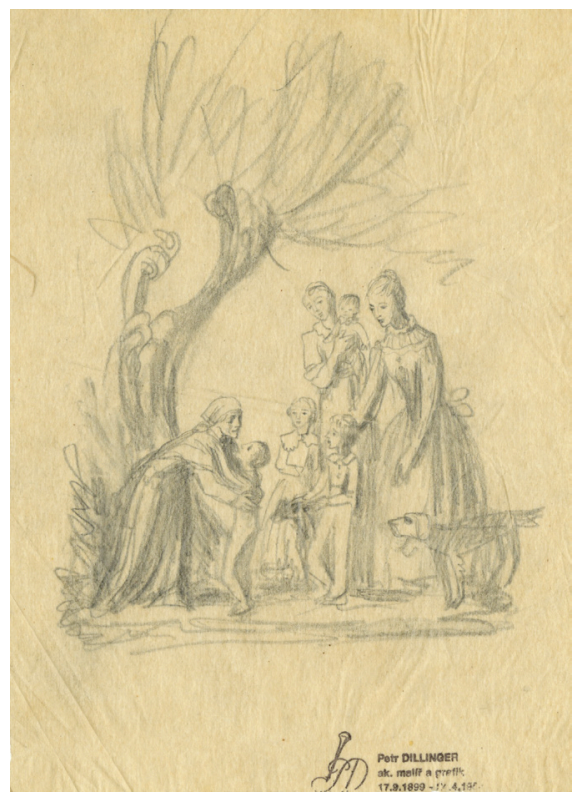

Obr. 1. Studie k ilustraci pro frontispis od Petra Dillingera ke knize Babička: obrazy venkovského života od Boženy Němcové. Praha: František Strnad, 1940. Edice Růžový palouček. Kresba tužkou. Foto: KNM.

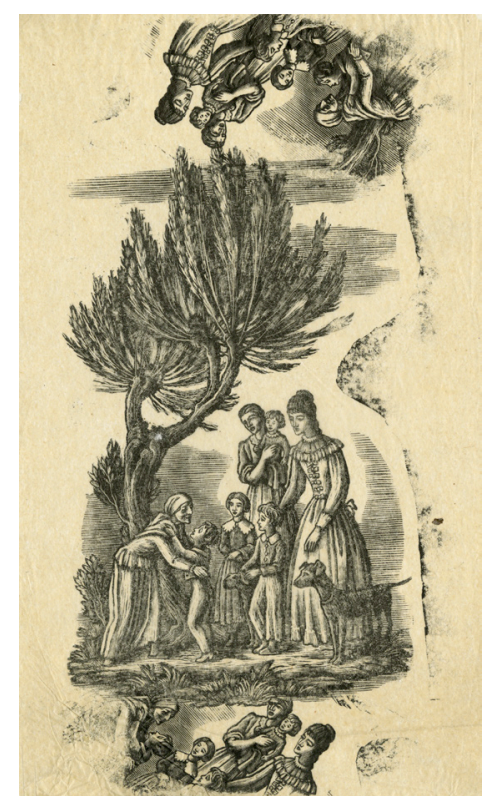

Obr. 2. Zkušební nátisky ilustrace pro frontispis od Petra Dillingera ke knize Babička: obrazy venkovského života od Boženy Němcové. Praha: František Strnad, 1940. Edice Růžový palouček. Dřevoryt. Foto: KNM.

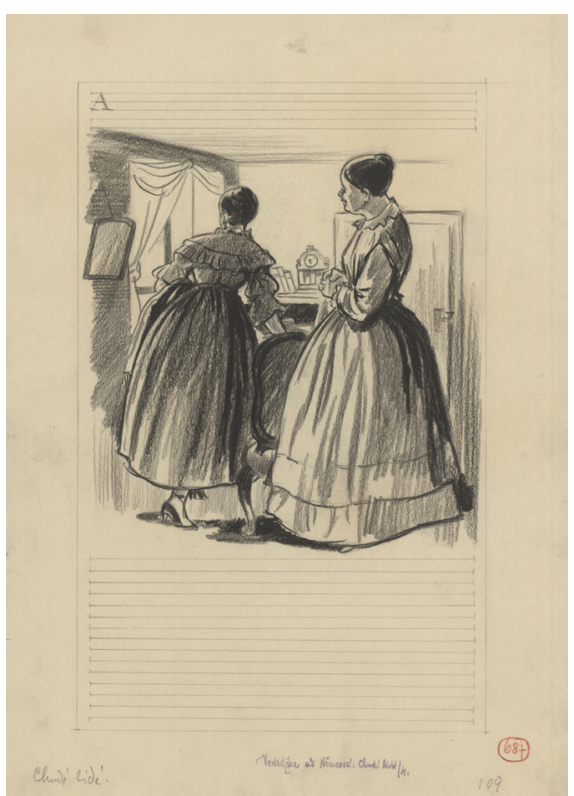

Obr. 3. llustrace a zrcadlo sazby od Josefa Vodrážky ke knize Boženy Němcové Chudí lidé a jiné povídky. Praha: Leopold Mazáč, 1932. Edice Němcová, Božena: Jubilejní ilustrovaná vydání nejkrásnějších knih. Kresba pastelem. Foto: KNM.

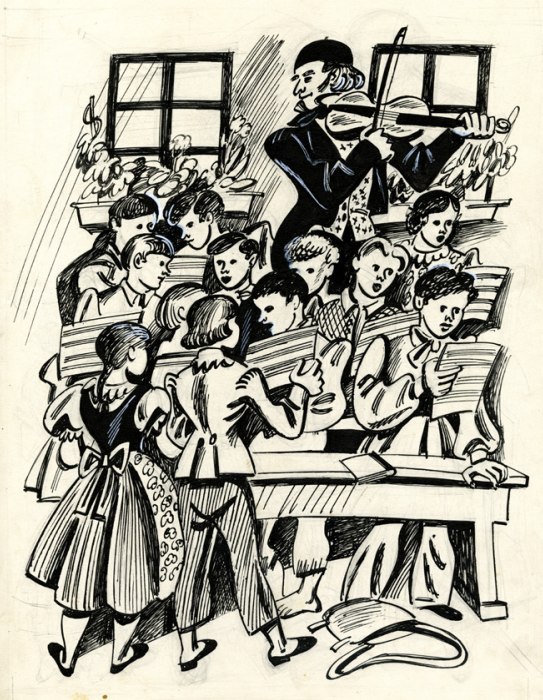

Obr. 4. Ilustrace Jaroslava Pecháčka ke knize Boženy Němcové Pan učitel. Hranice: Josef Hladký, 1937. Kresba tuší. Foto: KNM.

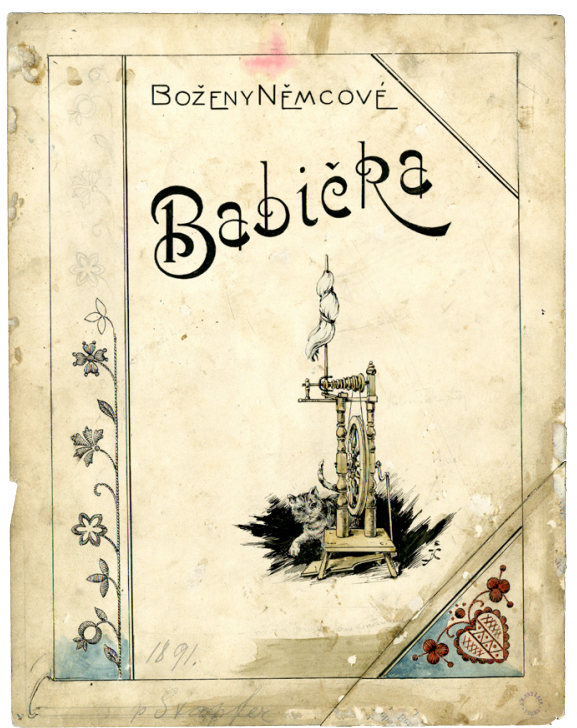

Obr. 5. Předloha pro obálku ke knize Boženy Němcové Babička od Karla Štapfera. Praha: I. L. Kober, 1891. Kresba tuší, akvarel. Foto: KNM. 


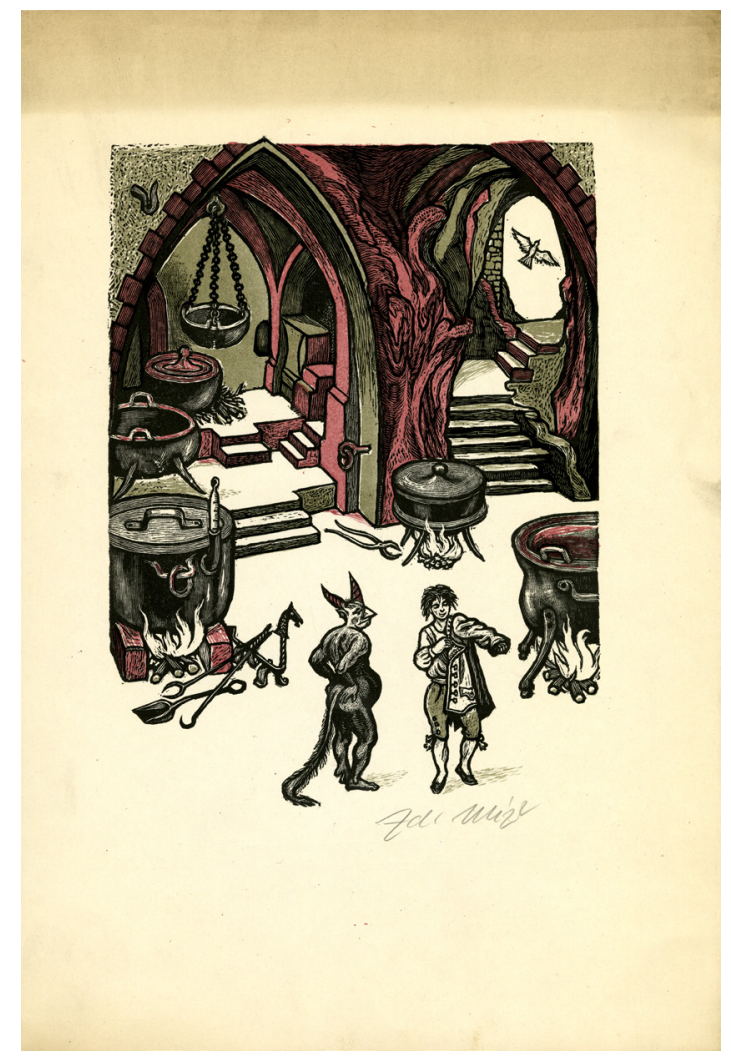

Obr. 6. Ilustrace Zdeňka Mézla k pohádce Boženy Němcové O Nesytovi z knihy Sůl nad zlato a jiné pohádky. Praha: Státní pedagogické nakladatelství, 1965. Dřevoryt. Foto: KNM.

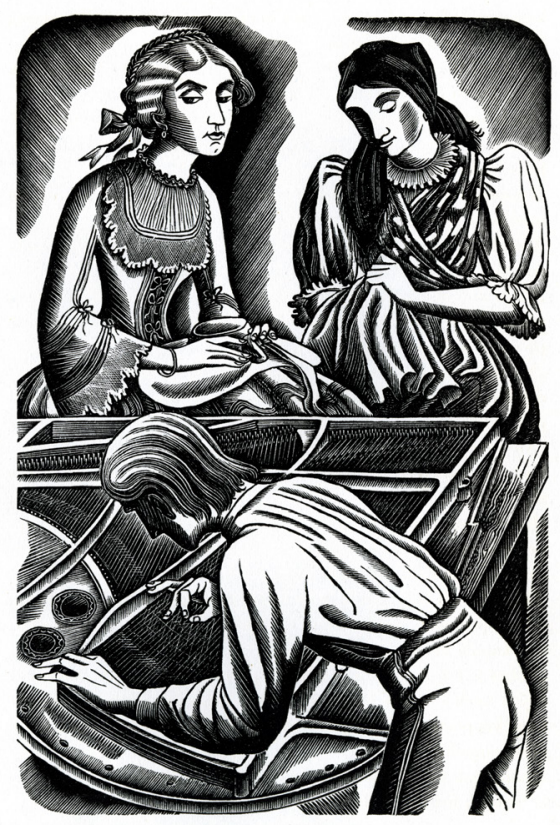

Obr. 8. Ilustrace Cyrila Boudy ke knize Boženy Němcové Pohorská vesnice. Praha: Státní nakladatelství krásné literatury a umění, 1962. Dřevoryt. Foto: KNM.

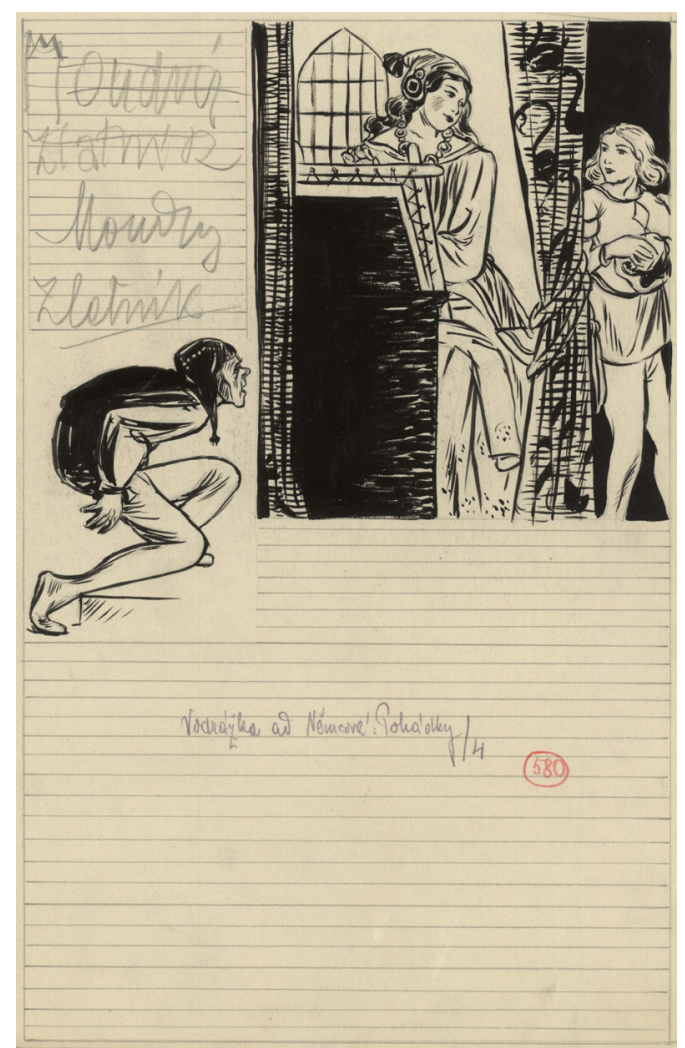

Obr. 7. Ilustrace a zrcadlo sazby od Josefa Vodrážky $k$ pohádce Boženy Němcové Bajaja z knihy Pohádky. Praha: Leopold Mazáč, 1932. Edice Němcová Božena: Jubilejní ilustrované vydání nejkrásnějších knih. Kresba tuší. Foto: KNM.

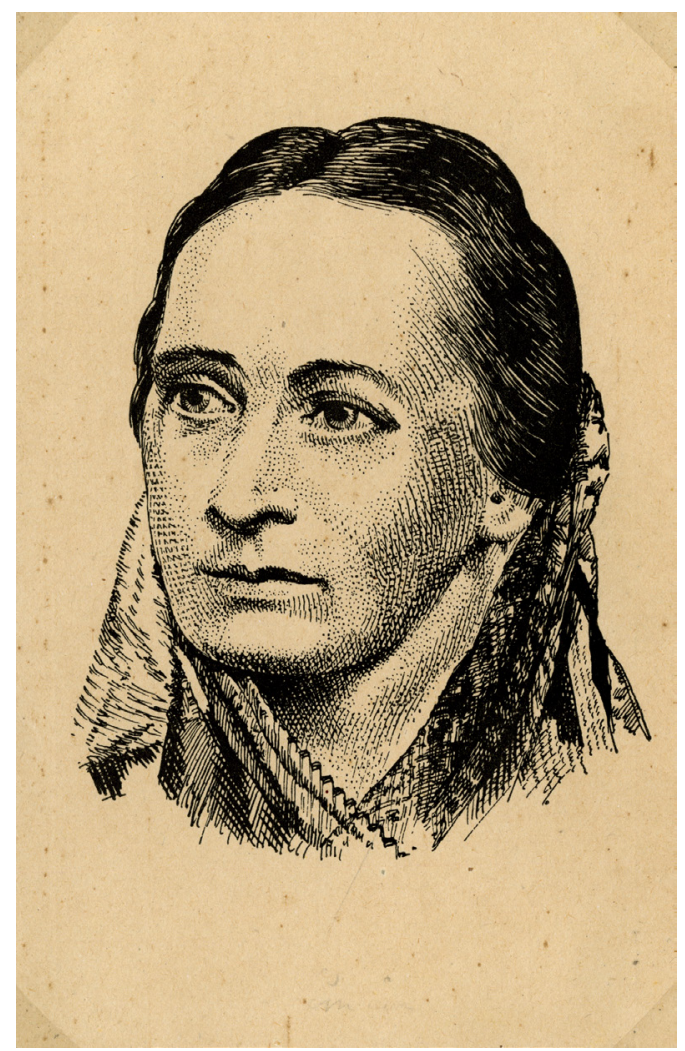

Obr. 9. Dopisnice s portrétem Boženy Němcové od Stanislava Kulhánka ze souboru Naši bohatýři. Praha: Josef Hladký, 1921. Zinkografie. Foto KNM. 